\title{
Aboriginal Title and Aboriginal Rights: What's The Connection?
}

\author{
KENT MCNEIL *
}

The author presents an analysis and critique of the current law and judicial treatment of legal issues relating to the rights of Aboriginal peoples. His focus is an examination of the connection between Aboriginal rights and Aboriginal title to land.

The author analyzes recent Supreme Court of Canada decisions which attempt to clarify the body of law in this area. R. v. Van der Peet, R. v. Adams, and $\mathbf{R}$. v. Côté reveal that Aboriginal title is just a subset of Aboriginal rights, and that freestanding Aboriginal rights such as hunting and fishing rights can exist independently of Aboriginal title. The author offers a critique of the Supreme Court of Canada's approach to identification and definition of Aboriginal rights, and contrasts it with the application of general principles relating to occupation of land in the context of a claim to Aboriginal title. His arguments are based in part on authorities from England, Australia and the United States.
$L$ 'auteur propose une analyse et une critique du droit actuel et de la façon dont les tribunaux traitent les questions d'ordre juridique liées awx droits des peuples autochtones. Il se penche plus particulièrement sur les liens entre les droits ancestraux et les titres aborigènes.

$L$ 'auteur examine les décisions récentes de la Cour suprême dans la trilogie R. c. Van der Peet, R. c. Adams et $\mathrm{R}$. c. Côté, révélant que le titre aborigène $n$ 'est qu'un sous-ensemble des droits autochtones, et que les droits naturels de pêche et de chasse peuvent exister indépendamment d'un titre aborigène. L'auteur critique l'approche adoptée par la Cour suprême en ce qui touche l'identification et la définition des droits autochtones, et la compare à l'application des principes généraux relatifs à l'occupation du territoire dans le contexte de la revendication d'un titre aborigène. Il s'appuie en partie sur des auteurs britanniques, australiens et américains.

\section{TABLE OF CONTENTS}

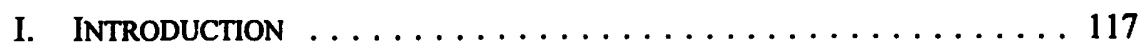

II. RECENT SUPREME COURT DECISIONS

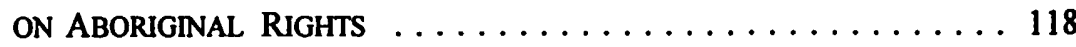

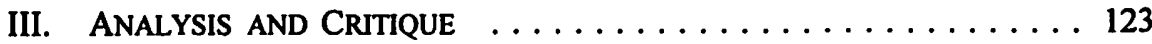

A. Proof of ABoriginal TItLE $\ldots \ldots \ldots \ldots \ldots \ldots \ldots \ldots \ldots$

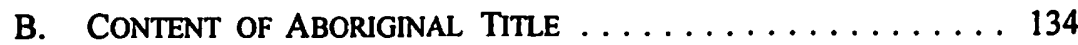

IV. ConcLUSION $\ldots \ldots \ldots \ldots \ldots \ldots \ldots \ldots \ldots \ldots \ldots \ldots \ldots \ldots \ldots \ldots$

\section{INTRODUCTION}

The jurisprudence relating to the rights of the Aboriginal peoples is probably the most uncertain and contentious body of law in Canada. A major reason for the uncertainty is no doubt the fact that when Canada was colonized by France and Britain there were no established civil or common law doctrines that could be applied to ascertain the status and rights of the peoples who occupied North America as independent nations prior to the imposition of European sovereignty. New law therefore had to be created to deal with this unique situation. As events preceded the formulation 
of legal norms, judges were left with the difficult task of trying to come up with appropriate rules to regulate relationships and determine rights long after the fact.

This process is still going on today. Remarkably, many major issues involving the rights of the Aboriginal peoples remain unresolved. For example, it is still uncertain whether Canadian law acknowledges that the Aboriginal peoples have an inherent right of self-government. The status, meaning and effect of treaties that many Aboriginal nations signed with the French, British and Canadian governments continue to be subject to debate. As recently as 1984, the Supreme Court of Canada decided for the first time that the Crown owes a legally-enforceable fiduciary duty to the Aboriginal peoples,' but the scope and consequences of that duty are still ambiguous. The list could go on. Gradually, however, the Supreme Court is providing more clarity and coherence to the distinctive body of law relating specifically to the Aboriginal peoples. In this article, I am going to focus on an issue that the Supreme Court has grappled with recently, and clarified to some extent - namely, the connection between Aboriginal rights generally and Aboriginal title to land.

\section{ReCENT Supreme Court Decisions on Aboriginal Rights}

The most important Aboriginal rights case decided by the Supreme Court of Canada in 1996 was undoubtedly R. v. Van der Peet. ${ }^{2}$ For the first time, the Court laid down a test for determining whether a particular activity is protected as an Aboriginal right for the purposes of s. 35(1) of the Constitution Act, 1982. ${ }^{3}$ In Lamer C.J.C.'s words, "in order to be an Aboriginal right an activity must be an element of a practice, custom or tradition integral to the distinctive culture of the Aboriginal group claiming the right." Moreover, in his view the time for applying this "integral to the distinctive culture" test is the period prior to contact between the Aboriginal group and Europeans. ${ }^{5}$ Because the Court found that the particular activity Dorothy Van der Peet had been engaged in when charged under the federal Fisheries $A c t^{6}$ - namely, exchanging fish for money or other goods - had not been an integral part of the distinctive culture of her people before Europeans arrived, it is not protected today as an Aboriginal right. Her conviction for selling fish caught under the authority of an Indian food fish licence was therefore upheld.

Both the "integral to the distinctive culture" test and the time frame for its application have been criticized elsewhere. ${ }^{7}$ In this article, my intention in this context

Guerin v. R, [1984] 2 S.C.R. 335 [hereinafter Guerin].

$R$ v. Van der Peet, [1996] 4 C.N.L.R. 177 (S.C.C.) [hereinafter Van der Peet].

Schedule B to the Canada Act 1982 (U.K.), 1982, c. 11. Section 35(1) provides: "The existing aboriginal and treaty rights of the aboriginal peoples of Canada are hereby recognized and affirmed." Van der Peet, supra note 2 at 201 (para. 46).

s Ibid. at 205-207. Compare L'Heureux-Dube and McLachlin JJ.'s dissenting opinions at 234-39 (paras. 164-79), 260-62 (paras. 244-50), respectively.

6 R.S.C. 1970 , c. F-14, s. 61, now R.S.C. 1985 , c. F-14, s. 79 (1).

I In addition to the dissenting judgments of L'Heureux-Dube and McLachlin JJ. in Van der Peet, see J. Borrows, "The Trickster: Integral to a Distinctive Culture" (1997) 8 Constitutional Forum 27; L.I. Rotman, "Hunting for Answers in a Strange Kettle of Fish: Unilateralism, Paternalism and Fiduciary 
is not to reassess the test as such, but rather to consider how it relates to the connection between Aboriginal rights and Aboriginal title to land, and to suggest how the test might apply to an Aboriginal title claim.

As Van der Peet involved a claim to an Aboriginal right to sell or exchange fish, Aboriginal title to land was not at issue in the case. However, Lamer C.J.C. did make the general statement that "Aboriginal title is the aspect of Aboriginal rights related specifically to Aboriginal claims to land; it is the way in which the common law recognizes Aboriginal land rights." $\mathrm{He}$ went on to say that "[b]oth Aboriginal title and Aboriginal rights arise from the existence of distinctive Aboriginal communities occupying "the land as their forefathers had done for centuries'." $\mathrm{He}$ did not, however, specify the circumstances in which occupation of land by an Aboriginal community would give rise to Aboriginal title, rather than to some other Aboriginal right or rights.

This issue of the connection between Aboriginal rights and title came before the Supreme Court more directly in the decisions it handed down six weeks after Van der Peet in R. v. Adams ${ }^{10}$ and R. v. Côté." Both of these cases arose in Quebec, and involved claims to an Aboriginal right to fish for food by a Mohawk from Akwesasne and Algonquins from the Maniwaki reserve, respectively. The issue of Aboriginal title was raised because in Adams the Crown argued, and in Côté all the parties assumed, that an Aboriginal right to fish could not exist apart from Aboriginal title to land. The Crown in each case denied that the Mohawks and Algonquins had such a title where the fishing took place. For this reason, Lamer C.J.C., who wrote the principal judgment in each case, stated the main issue in these terms in Adams:

In resolving this appeal and the appeal in Côté, this Court must answer the question of whether Aboriginal rights are necessarily based in Aboriginal title to land, so that the fundamental claim that must be made in any Aboriginal rights case is to Aboriginal title, or whether Aboriginal title is instead one sub-set of the larger category of Aboriginal rights, so that fishing and other Aboriginal rights can exist independently of a claim to Aboriginal title. $^{12}$

Lamer C.J.C. resolved this question in each case by deciding that Aboriginal title is indeed a sub-set of Aboriginal rights, so a free-standing Aboriginal right such as a right to fish for food can exist independently of Aboriginal title. For this, and other reasons

Rhetoric in Badger and Van der Peet" (1997) 8 Constitutional Forum 40; K. McNeil, "Reduction by Definition: The Supreme Court's Treatment of Aboriginal Rights in 1996" (1997) 5: 3 \& 4 Canada Watch 60; J. Gray, "O Canada! - Van der Peet as Guidance on the Construction of Native Title Rights" (1997) 2:1 Australian Indigenous Law Reporter 18; K. Gallagher-Mackay, "Interpreting SelfGovernment: Approaches to Building Cultural Authority" [1997] 4 C.N.L.R. (forthcoming).

- Van der Peet, supra note 2 at 194 (para. 33).

9 Ibid. quoting from Judson J.'s judgment in Calder v. British Columbia (A.G.), [1973] S.C.R. 313 at 328 [hereinafter Calder] (Calder, of course, did involve an Aboriginal title claim).

$10 R$ v. Adams, [1996] 4 C.N.L.R. 1 (S.C.C.) [hereinafter Adams].

" $R$ v. Côté, [1996] 4 C.N.L.R. 26 (S.C.C.) [hereinafter Côté].

12 Adams, supra note 10 at 4 (para. 3). See also Côté, ibid. at 31 (para. 3). 
which are not relevant to our discussion, he decided the appeals in favour of the accused, with one exception. ${ }^{13}$

Lamer C.J.C.'s more extensive treatment of the connection between Aboriginal title and Aboriginal rights is found in Adams. In that decision, he supported his conclusion that Aboriginal rights can exist independently of Aboriginal title by reference to the "integral to the distinctive culture" test laid down in Van der Peet. In an important passage that deserves to be quoted in full, he wrote:

What this test, along with the conceptual basis which underlies it, indicates, is that while claims to Aboriginal title fall within the conceptual framework of Aboriginal rights, Aboriginal rights do not exist solely where a claim to Aboriginal title has been made out. Where an Aboriginal group has shown that a particular activity, custom or tradition taking place on the land was integral to the distinctive culture of that group then, even if they have not shown that their occupation and use of the land was sufficient to support a claim of title to the land, they will have demonstrated that they have an Aboriginal right to engage in that practice, custom or tradition. The Van der Peet test protects activities which were integral to the distinctive culture of the Aboriginal group claiming the right; it does not require that the group satisfy the further hurdle of demonstrating that their connection with the piece of land on which the activity was taking place was of a central significance to their distinctive culture sufficient to make out a claim to Aboriginal title to the land. Van der Peet establishes that s.35 [of the Constitution $\mathrm{ACl}, 1982$ ] recognizes and affirms the rights of those peoples who occupied North America prior to the arrival of the Europeans; that recognition and affirmation is not limited to those circumstances where an Aboriginal group's relationship with the land is of a kind sufficient to establish title to the land."

What Lamer C.J.C. seems to have in mind are different kinds or degrees of connection with the land, some of which are adequate to make out an Aboriginal right to fish or carry on other activities on that land without being sufficient to establish Aboriginal title. This is apparent from the reliance he placed on the relationship Aboriginal peoples have with the land as an element that underlies some of their Aboriginal rights. In a passage from Van der Peet which he quoted in support of his analysis in Adams, Lamer C.J.C. linked this relationship with Aboriginal cultures:

Aboriginal rights arise from the prior occupation of land, but they also arise from the prior social organization and distinctive cultures of Aboriginal peoples on that land. In considering whether a claim to an Aboriginal right has been made out, courts must look at both the relationship of an Aboriginal claimant to the land and at the practices, customs and traditions arising from the claimant's distinctive culture and society. ${ }^{\text {s }}$

13 The exception was that the convictions of the accused in Côté, ibid. under the Regulation respecting controlled zones, R.R.Q. 1981, Supp., at 370, s. 5.1, were upheld because the Court decided that that Regulation, unlike the Quebec Fishery Regulations, C.R.C., C. 852, s. 4(1), did not infringe the accused's Aboriginal right to fish for food.

14 Adams, supra note 10 at 11 (para. 26) [emphasis in original]. Lamer C.J.C. quoted from and relied on this passage in coming to the same conclusion in Côté, supra note 11 at 42 (para. 38).

is Adams, ibid. at 12 (para. 29) [emphasis in original], quoting from Van der Peet, supra note 2 at 210 (para. 74). 
Moreover, Lamer C.J.C. said in Adams that an Aboriginal right to hunt or fish that exists independently of Aboriginal title may still be site-specific so that it can only be practised on the tract of land where those activities have historically been carried out by the Aboriginal people claiming the right. In his words, "[a] site-specific hunting or fishing right does not, simply because it is independent of Aboriginal title to the land on which it took place, become an abstract fishing or hunting right exercisable anywhere; it continues to be a right to hunt or fish on the tract of land in question." 16 However, while Lamer C.J.C. affirmed in Côté that "an Aboriginal right will often be defined in site-specific terms," Given that Aboriginal rights which are not site-specific would not depend on occupation of specific land, occupation of land does not seem to be a requirement for every Aboriginal right.

Although Lamer C.J.C. did not specify the degree of occupation of land required to establish Aboriginal title, evidently he regarded permanence of occupation as a factor to be taken into account. In Adams, he wrote:

To understand why Aboriginal rights cannot be inexorably linked to Aboriginal title it is only necessary to recall that some Aboriginal peoples were nomadic, varying the location of their settlements with the season and changing circumstances. That this was the case does not alter the fact that nomadic peoples survived through reliance on the land prior to contact with Europeans and, further, that many of the customs, practices and traditions of nomadic peoples that took place on the land were integral to their distinctive cultures. ${ }^{\text {is }}$

Continuing this line of thought, Lamer C.J.C. added:

Moreover, some Aboriginal peoples varied the location of their settlements both before and after contact. The Mohawks are one such people.... That this is the case may (although I take no position on this point) preclude the establishment of Aboriginal title to the lands on which they settled; however, it in no way subtracts from the fact that, wherever they were settled before or after contact, prior to contact the Mohawks engaged in practices, traditions or customs on the land which were integral to their distinctive culture. ${ }^{19}$

The picture which emerges from Lamer C.J.C.'s discussions of the relationship between Aboriginal title and Aboriginal rights in Adams and Côté can be summarized as follows. Aboriginal title depends on proof of a connection with specific land that meets an as yet undefined threshold of sufficient occupation, one aspect of which is a degree of permanence that is also undefined. Moreover, a literal reading of Lamer C.J.C.'s judgment in Adams suggests that the connection with the land must have been integral to the distinctive culture of the Aboriginal people in question prior to contact with Europeans. Free-standing Aboriginal rights, such as a right to hunt or fish, may or may not involve a connection with specific lands, but even where such a connection 
exists and makes the rights site-specific, the degree and permanence of the occupation is less than that required for Aboriginal title. Also, in the case of these free-standing rights it seems that it is the activity on the land that must be integral to the distinctive culture of the Aboriginal people in question rather than the connection with the land itself. Moreover, while some Aboriginal peoples may be unable to claim Aboriginal title because they were "nomadic" and so did not have a sufficiently permanent connection with any land, apparently all Aboriginal people would be entitled to some Aboriginal rights, as Lamer C.J.C. wrote in Adams that "[t]he Aboriginal rights recognized and affirmed by s.35(1) should not be understood or defined in a manner which excludes some of those the provision was intended to protect."20 Finally, even where free-standing Aboriginal rights are site-specific, apparently the locations where they may be practised can shift even after contact, as could have happened in the case of the Mohawks. However, Lamer C.J.C. expressly left undecided the question of whether Aboriginal title can shift from lands where an Aboriginal people had a sufficient connection prior to contact to other lands where they established such a connection after contact.

Another major issue which was left undecided in the above cases is the nature or content of Aboriginal title. Van der Peet, Adams and Côté clarified that the nature of free-standing Aboriginal rights depends on the activities engaged in by an Aboriginal people that were elements of practices, customs and traditions integral to their distinctive culture prior to European contact. ${ }^{21}$ But while Adams and Côté, by classifying Aboriginal title as a sub-set of Aboriginal rights, indicate that the "integral to the distinctive culture" test may apply to Aboriginal title as well as to other Aboriginal rights, the implications of this for the content of Aboriginal title remain unclear. In my view, this will depend on how the test is applied.

One possibility would be to apply the test only to determine whether an Aboriginal people had a connection with specific land prior to European contact that meets the undefined threshold required for Aboriginal title. If they could prove they had a connection that was integral to their distinctive culture, they would have Aboriginal title. The content of that title would then be determined by general principles relating to occupation of land rather than by their specific pre-contact activities on that land. A second possible approach would be to apply the "integral to the distinctive culture" test not just to determine whether they had the requisite connection with the land, but also to determine the content of their Aboriginal title after that connection had been established. For reasons to be elaborated below, an approach that applies the test to the establishment but not to the content of Aboriginal title is preferable because it is more in accord with common law principles and accepted norms of non-discrimination, and conforms with established judicial precedents.

$20 \quad$ Ibid. (para. 27).

${ }^{21}$ See also R. v. Gladstone, [1996] 4 C.N.L.R. 65 (S.C.C.); R. v. N.T.C. Smokehouse Ltd., [1996] 4 C.N.L.R. 130 (S.C.C.); R. v. Pamajewon, [1996] 4 C.N.L.R. 164 (S.C.C.). 


\section{Analysis and Critique}

\section{A. Proof of aboriginal title}

In our discussion of Van der Peet, Adams, and Côté, we saw that free-standing Aboriginal rights such as a right to hunt or fish can be proven by showing that the activity in question was an element of a practice, custom or tradition integral to the distinctive culture of the Aboriginal people claiming the right prior to contact with Europeans. Free-standing Aboriginal rights may or may not be site-specific, depending on whether their exercise was connected to specific lands at the relevant time. Aboriginal title, on the other hand, seems to involve proof of a connection with the land itself that was integral to the distinctive culture of the Aboriginal claimants. Moreover, this connection must somehow be greater and more permanent than the connection required to establish a site-specific Aboriginal right. Finally, if the Van der Peet time frame for establishing a free-standing Aboriginal right is applied to Aboriginal title, the requisite connection with the land would have to be proven to have existed prior to the time of European contact. Each of these elements of the connection with the land approach will be analyzed in turn.

\section{A Connection Integral to the Distinctive Culture}

In order to determine how the "integral to the distinctive culture" test might apply to Aboriginal title, we need to examine it more closely. In Van der Peet, Lamer C.J.C. elaborated on the test by explaining some of the factors a court should consider in determining the existence of an Aboriginal right. First of all, he said that the perspective of the Aboriginal people claiming the right must be taken into account. However, he qualified this by saying that "that perspective must be framed in terms cognizable to the Canadian legal and constitutional structure."22 He justified this qualification by adopting a purposive analysis of s. 35(1) of the Constitution Act, 1982 . From this analysis, he concluded that "what s. 35(1) does is provide the constitutional framework through which the fact that Aboriginals lived on the land in distinctive societies, with their own practices, traditions and cultures, is acknowledged and reconciled with the sovereignty of the Crown." ${ }^{23}$ Sensitivity to the Aboriginal perspective therefore has to be balanced with the common law perspective of the nonAboriginal legal system. ${ }^{24}$

The next factor a court must look at is the nature of the Aboriginal right being claimed. Lamer C.J.C. provided the following directions to guide this stage of the inquiry:

To characterize an applicant's claim correctly, a court should consider such factors as the nature of the action which the applicant is claiming was done pursuant to an Aboriginal right, 
the nature of the governmental regulation, statute or action being impugned, and the tradition, custom or practice being relied upon to establish the right. ${ }^{25}$

Once the nature of the claimed right has been correctly identified, a court has to determine whether the practice, custom or tradition relied upon to establish it was "a central and significant part of the [Aboriginal] society's distinctive culture. ${ }^{26}$ Here the burden lies on the claimant to demonstrate "that the practice, tradition or custom was one of the things which made the culture of the society distinctive - that it was one of the things that truly made the society what it was." ${ }^{27}$ Lamer C.J.C. explained further that

[t]he court cannot look at those aspects of the Aboriginal society that are true of every human society (e.g., eating to survive), nor can it look at those aspects of the Aboriginal society that are only incidental or occasional to that society; the court must look instead to the defining and central attributes of the Aboriginal society in question. ${ }^{28}$

However, while the practice, custom or tradition has to be "distinctive" in the sense that it is a distinguishing characteristic of the society, it does not have to be "distinct" in the sense of being unique. ${ }^{29}$

I have difficulty reconciling Lamer C.J.C.'s assertion that the practice, custom or tradition in question does not have to be distinct with his statement that it cannot be an aspect of the society which is true of every human society. Why should it be disqualified because it happens to be common to all rather than just many human societies, as long as it is a defining characteristic of the society in question? Lamer C.J.C. himself gave the example of fishing for food, which was acknowledged to be an Aboriginal right of the Musqueam Nation in $R$. v. Sparrow. ${ }^{30}$ As he pointed out, fishing for food is hardly distinct in the sense of being unique to the Musqueams, as it is practiced by many societies around the world. ${ }^{31}$ So would it cease to qualify as an Aboriginal right, as Lamer C.J.C. seems to have suggested, if it were shown that all human societies fish for food? With all due respect, that would make no sense, as it would not make fishing for food any less distinctive for the Musqueams. I therefore think that one should disregard Lamer C.J.C.'s obiter dictum about aspects of an Aboriginal society that are true of every human society.

Now that we have a clearer idea of what the "integral to the distinctive culture" test involves, we can attempt to assess its application to an Aboriginal title claim. As it seems to be the connection with the land that must be integral to the distinctive culture where Aboriginal title is concerned, we need to determine what is required to establish that connection.

2s lbid. at 203 (para. 53).

25 Ibid. at 204 (para. 55).

27 lbid. [emphasis in original].

28 Ibid. (para. 56).

29 lbid. at 209 (para. 71).

30 $\quad R$ v. Sparrow, [1990] 3 C.N.L.R. 160 (S.C.C.) [hereinafter Sparrow].

31 Van der Peet, supra note 2 at 209 (para. 72). 
Following Lamer C.J.C.'s directions, first we need to take into account the perspective of the Aboriginal people making the claim. This could be revealed by testimony from their elders as custodians of the people's oral history and traditions. As Lamer C.J.C. said that this perspective must be framed in terms cognizable to the nonAboriginal legal system, interpretive testimony from anthropologists and other outside experts would probably be of assistance as well. However, that testimony should not be allowed to overshadow the evidence provided by the Aboriginal people themselves because it is their perspective - not the perspective of non-Aboriginal observers and interpreters - that must be ascertained. ${ }^{32}$

According to Lamer C.J.C., the next factor to be considered is the nature of the right being claimed. In this respect, a claim to Aboriginal title is qualitatively different from a claim to free-standing rights, such as a right to hunt or fish. The latter amounts to rights to pursue activities on the land, whereas Aboriginal title amounts to a right to the land itself. Conceptually, therefore, Aboriginal title is different from a collection of rights to pursue various activities on the land, each of which could be established as a free-standing right, as in Adams and Côté, without any need to establish title to the land itself. A claim to Aboriginal title would therefore seem to involve a claim that the land belonged to the Aboriginal claimants, in accordance with their practices, customs and traditions, and taking account of their own perspective. Considering such a claim in terms cognizable to the common law legal system, ${ }^{33}$ it would be akin to a claim to ownership $^{34}$ If established, it should entitle the claimants to conduct any activities permitted by law on the land for as long as their title endures. While at common law the Crown may have the underlying title to the land as a concomitant of sovereignty, ${ }^{35}$ as will be discussed in more detail below this does not mean that the Crown has any beneficial interest.

After the nature of the claimed right has been identified, Lamer C.J.C. said that it has to be determined whether the practice, custom or tradition relied on to establish it was a central and significant part of the Aboriginal society's distinctive culture. In the context of an Aboriginal title claim, relevant practices would encompass the activities and ceremonies the people conducted in relation to the land, including the use they made of the land for their physical needs. No doubt these practices would be intertwined with their customs and traditions. Taking into account their perspectives,

32 See the discussion in J. Borrows \& L.I. Rotman, "The Sui Generis Nature of Aboriginal Rights: Does It Make a Difference?" (1997) 36 Alta. L. Rev. 9; J.Y. Henderson, "Interpreting Sui Generis Treaties" (1997) 36 Alta. L. Rev. 46.

33 Note that, while the civil law system generally applies to property rights in Quebec, throughout Canada "the law of Aboriginal title represents a distinct species of federal common law rather than a simple subset of the common or civil law or property law operating within the province": Coté, supra note 11 at 47 (para. 49), relying on Roberts v. Canada, [1989] 1 S.C.R. 322 at 340. See generally B. Rudden, "The Terminology of Title" (1964) 80 L.Q. Rev. 63; A.M. Honoré, "Ownership" in A.G. Guest, ed., Oxford Essays in Jurisprudence (Oxford: Oxford University Press, 1961) 107.

35 See Sparrow, supra note 30 at 177; Mabo v. Queensland [No. 2] (1992) 175 C.L.R. 1 at $41-52$ (H.C. Aust.), Brennan J. (as he then was) [hereinafter Mabo]; and, more generally, K. McNeil, Common Law Aboriginal Title (Oxford: Clarendon Press, 1989) especially 79-107, 216-21 [hereinafter Common Law Aboriginal Title]. 
their relationship with the land would likely be multi-dimensional, involving spiritual elements, responsibilities, and a sense of belonging, as well as physical sustenance. Given the undeniable significance that Aboriginal peoples generally attribute to the land and their relationship to it, ${ }^{36}$ proving a connection with the land that was integral to their distinctive culture in the sense of being central to their existence as a society would probably not present much difficulty for most Aboriginal peoples.

\section{Occupation and Use Necessary to Establish the Connection}

We have seen that to establish Aboriginal title a greater and more permanent connection with the land is required than for a free-standing Aboriginal right, such as a site-specific fishing right. ${ }^{37}$ But what kind of connection is necessary? Lamer C.J.C.'s judgments in Adams and Côté provide scant guidance to answer this question, apart from his intimation that peoples who "were nomadic, varying the location of their settlements with the season and changing circumstances," might not qualify. ${ }^{38} \mathrm{He}$ nonetheless suggested that Aboriginal title would be proven if the claimants could show "that their occupation and use of the land was sufficient to support a claim of title to the land."39 This implies some kind of threshold or standard of occupation and use which, if met, would establish the claimants' Aboriginal title. Following Lamer C.J.C.'s instructions, this standard should be identified by taking the perspectives of the Aboriginal peoples and the non-Aboriginal legal system into account.

At common law, occupation and use are closely related because proof of occupation of land usually depends on evidence of use. ${ }^{40}$ Generally, any acts in relation to land that indicate an intention to hold it for one's own purposes are evidence of occupation. ${ }^{41}$ However, occupation is a relative matter, depending on the nature of the land and the uses to which it can practically be put at the time. ${ }^{42}$ For example, in Red House Farms (Thorndon) Ltd. v. Catchpole, the English Court of Appeal decided that shooting on a regular basis over a marshy, undeveloped tract of land was sufficient to establish occupation. ${ }^{43}$ Moreover, "the conditions of life and the habits and ideas

See Report of the Royal Commission on Aboriginal Peoples, Restructuring the Relationship, vol. 2, part 2 (Ottawa: Minister of Supply and Services Canada, 1996) at 421-64 [hereinafter Royal Commission on Aboriginal Peoples].

See text accompanying notes 14-20, supra.

Adams, supra note 10 at 12 (para. 27).

39 Ibid. at 11 (para. 26) [emphasis in original] (for context for this quotation, see text accompanying note 14, supra).

40 For more detailed discussion, see Common Law Aboriginal Tille, supra note 35 at 197-204.

"I See generally F. Pollock \& R.S. Wright, An Essay on Possession in the Common Law (Oxford: Clarendon Press, 1888) at 28-36; J.M. Lightwood, A Treatise on Possession of Land (London: Stevens \& Sons, 1894) at 9-27; R.D.C. Stewart, "The Differences Between Possession of Land and Chattels" (1933) 11 Can. Bar Rev. 651 at 652-56.

42 See Lord Advocate v. Lord Lovat (1880), 5 App. Cas. 273 at 288 (H.L.); Kirby v. Cowderoy, [1912] A.C. 599 at 602-603 (P.C.) [hereinatter Kirby]; Wuta-Ofei v. Danquah, [1961] 3 All E.R. 596 at 600 (P.C.).

43 (1976), 244 E.G. 295 (C.A.) (leave to appeal to the House of Lords refused) [hereinafter Red House Farms]. See also Harper v. Charlesworth (1825), 4 B. \& C. 574 (K.B.). In Curzon v. Lomax (1803), 5 Esp. 60 (K.B.), and Bristow v. Cormican (1874), I.R. 10 C.L. 398 at 408 (Ex.), aff'd(1878), 3 App. Cas. 641 (H.L.), fishing was accepted as evidence of occupation. 
of the people" living in the locality are factors to be considered. ${ }^{44}$ The common law therefore supports an approach that would set a standard of occupation for Aboriginal title that takes the Aboriginal peoples' ways of life and customs into account. This approach also entails the kind of balance Lamer C.J.C. had in mind between the perspectives of the Aboriginal peoples and the non-Aboriginal legal system.

Applying common law authorities on relativity of occupation, and taking the Aboriginal peoples' perspectives into account, we need to reassess Lamer C.J.C.'s obiter suggestion that nomadic peoples would not qualify for Aboriginal title. If he meant that people who wandered from place to place without forming any lasting attachment to any particular tract of land would not be in occupation, he is probably right. But in fact it is very doubtful whether any Aboriginal people lived that way prior to European colonization of what is now Canada. To survive in what were often harsh environments, hunting and gathering peoples had to have an intimate knowledge of the land and the seasonal and other resources it provided. Rather than wander indiscriminately, they would return on a regular basis to the places where food and the other materials for the maintenance of their ways of life were available. They formed deep attachments with the land they knew and used, usually involving obligations to care for and conserve it as they derived their sustenance from it, all of which was intertwined with their spiritual and socio-political as well as their physical existence. ${ }^{45}$ As stated in the Report of the Royal Commission on Aboriginal Peoples,

[b]efore the arrival of Europeans, virtually all of Canada was inhabited and used by Aboriginal peoples. Whether they were comparatively settled fishers and horticulturalists or wide-ranging hunters, each people occupied specific territories and had systems of tenure, access and resource conservation that amounted to ownership and governance - although those systems were not readily understood by Europeans, in part because of language and cultural differences. ${ }^{46}$

Although of a different nature, the connection of hunter-gatherers with the land would be just as integral to their distinctive cultures as that of horticulturalists. Evaluating their connection with the land on the basis of their conditions of life and their own perspectives, they would no doubt be in occupation. This was the conclusion

4 Cadija Umma v. S. Don Manis Appu (1938), [1939] A.C. 136 at 141-42 [hereinafter Cadija Umma]. See also Sherren v. Pearson (1887), 14 S.C.R. 581 at 585-86; Halifax Power Co. v. Christie (1915), 48 N.S.R. 264 at 267.

is See Royal Commission on Aboriginal Peoples, supra note 36 at 434-37, 448-64.

4 Ibid. at 452. For examples of studies of specific Aboriginal peoples, see H. Hickerson, "Land Tenure of the Rainy Lake Chippewa at the Beginning of the 19th Century" (1967) 2 Smithsonian Contributions to Anthropology 41; J. Helm, "The Nature of Dogrib Socioterritorial Groups" in R.B. Lee \& I. DeVore, eds., Man the Hunter (New York: Aldine Publishing, 1968) 118; H. Brody, Maps and Dreams: Indians and the British Columbia Frontier (Harmondsworth, U.K.: Penguin Books, 1983). More generally, see R. Dyson-Hudson \& E.A. Smith, "Human Territoriality: An Ecological Reassessment" (1978) 80 American Anthropologist 21; D. Riches, Northern Nomadic HunterGatherers: A Humanistic Approach (London: Academic Press, 1982) especially 107-33; T. Ingold, "Territoriality and Tenure: The Appropriation of Space in Hunting and Gathering Societies" in The Appropriation of Nature: Essays on Human Ecology and Social Relations (lowa City: University of Iowa Press, 1987) 130-64. 
the United States Supreme Court reached over 160 years ago in Mitchel v. United States, where Baldwin J., for the Court, said the Indian occupation "was considered with reference to their habits and modes of life; their hunting-grounds were as much in their actual possession as the cleared fields of the whites." ${ }^{.97}$

\section{The Time Frame for Proving Aboriginal Title}

A final issue to address in the context of proof of Aboriginal title is the question of when the requisite connection with the land has to be shown to have existed. It will be recalled that in Van der Peet Lamer C.J.C. said that the practice, custom or tradition relied on as the basis of an Aboriginal right must have been integral to the distinctive culture of the claimants prior to contact with Europeans. He justified this by saying that, "[b]ecause it is the fact that distinctive Aboriginal societies lived on the land prior to the arrival of Europeans that underlies the Aboriginal rights protected by s.35(1) [of the Constitution Act, 1982], it is to that pre-contact period that the courts must look in identifying Aboriginal rights." ${ }^{48}$

Moreover, in addition to proof that the practice, custom or tradition was integral to the society prior to contact, it appears that continuity with a present-day practice, custom or tradition must also be established. ${ }^{49}$ However, Lamer C.J.C. said that the continuity concept does not require "evidence of an unbroken chain of continuity between their current practices, traditions and customs, and those which existed prior to contact." ${ }^{\text {" }}$ But while an interruption in a practice, custom or tradition will not preclude the present-day existence of an Aboriginal right, Lamer C.J.C. took no position on the question of whether an Aboriginal right can be lost as a result of the disappearance of the practice, custom or tradition on which it was based. ${ }^{51}$

Lamer C.J.C.'s pre-contact time frame for proof of Aboriginal rights was criticized by both L'Heureux-Dubé and McLachlin JJ. in their dissenting judgments in Van der Peet. ${ }^{52}$ Rather than enter that debate where Aboriginal rights in general are concerned, I am going to focus my comments on the inapplicability of that time frame to a claim to Aboriginal title. We have seen that Lamer C.J.C. apparently accepted in Van der Peet, Adams, and Côté that Aboriginal title involves rights to the land itself, rather than just rights to exercise activities on the land. Rights to land are necessarily proprietary in nature. While Aboriginal title may not fit into any common law

9 Pet. 711 at 746 (1835). See also United States v. Santa Fe Pacific Railroad Co., 314 U.S. 339 at 345-46 (1941); Northwestern Shoshone Indians v. United States, 324 U.S. 335 at 338-40 (1945); Sac and Fox Tribe v. United States, 383 F. 2d 991 at 998 (U.S. Ct. Cl. 1967) [hereinafter Sac and Fox Tribe]; United States v. Seminole Indians, 180 Ct. Cl. 375 at 383-86 (U.S. Ct. Cl. 1967).

4 Ibid. at 205-207 (paras. 63-65).

so Ibid. at 206 (para. 65).

s1 Ibid. at 206-207 (paras. 63-65). Compare R. v. Sioui, [1990] 3 C.N.L.R. 127 at 154, where Lamer $J$. (as he then was) held that a treaty right would not be lost by non-user.

s2 Van der Peet, supra note 2 at 234-39 (paras. 164-79), 260-62 (paras. 244-50). 
categories of real property because it has been classified as sui generis, ${ }^{53}$ it is nonetheless an interest in land that enjoys legal protection like any other property interest. ${ }^{54}$ However, it differs from most other interests in land because it originates in the Aboriginal peoples' occupation and use of lands prior to acquisition of sovereignty by the Crown, and is inalienable other than by surrender to the Crown. ${ }^{55}$

As a general rule, when the British Crown acquired a new colony, the land rights of the inhabitants were presumed to continue in the absence of proof that the Crown extinguished those rights by an act of state prior to or in the process of acquiring sovereignty. ${ }^{56}$ Along with sovereignty, the Crown generally would have acquired absolute title to vacant, unowned lands, as well as an underlying title to lands that were subject to pre-existing rights. ${ }^{57}$ However, if Lamer C.J.C.'s time frame for proof of other Aboriginal rights is applied to Aboriginal title, the time for determining the existence of that title is not when the Crown acquired sovereignty, but when European contact occurred..$^{58}$ Leaving aside the complicating factor of prior French sovereignty in parts of Canada, ${ }^{59}$ and concentrating our discussion on the regions where the British

33 See Guerin, supra note 1 at 379-82, Dickson J. (as he then was); Borrows \& Rotman, supra note 32 at 21.

54 See St. Catherine's Milling and Lumber Company v. The Queen (1888), 14 App. Cas. 46 at 58 (P.C.); Canadian Pacific Limited v. Paul, [1988] 2 S.C.R. 654 at 677. For more detailed discussion, see B. Slattery, "Understanding Aboriginal Rights" (1987) 66 Can. Bar Rev. 727 at 748-51; K. McNeil, "The Temagami Indian Land Claim: Loosening the Judicial Strait-jacket" in M. Bray \& A. Thomson, eds., Temagami: A Debate on Wilderness (Toronto: Dundurn Press, 1990) 185, especially 189-91 [hereinafter "Loosening the Judicial Strait-jacket"] and "Racial Discrimination and Unilateral Extinguishment of Native Title" (1996) I Australian Indigenous Law Reporter 181 at 205-207 [hereinafter "Racial Discrimination"]. Compare Delgamuukw v. British Columbia (1993), 104 D.L.R. (4th) 470, Macfarlane J.A. at 510-11, Wallace J.A. at 573, Lambert J.A. (dissenting on other grounds) at 649-50, Hutcheon J.A. (dissenting on other grounds) at 755-56 [hereinafter Delgamuukw]. In fact, Aboriginal title should enjoy more protection than other property interests because it has been constitutionally recognized and affirmed by s. 35(1) of the Constitution Act, 1982, whereas other property interests have not.

ss Guerin, supra note 1 at 376-82, Dickson J. On inalienability of Aboriginal title, see notes 76 and 112 , infra.

s6 See Witrong v. Blany, (1674) 3 Keb. 401 at 402; Amodu Tijani v. Secretary, Southern Nigeria, [1921] 2 A.C. 399 at 407, 410 (P.C.); Oyekan v. Adele, [1957] 2 All E.R. 785 at 788 (P.C.); and discussion in Common Law Aboriginal Title, supra note 35 at 161-92.

57 Mabo, supra note 35 at 43-52, Brennan J. Note, however, that the Crown probably would not have acquired an underlying title to lands that were owned allodially, as on the Shetland and Orkney Islands in Scotland: see Smith v. Lerwick Harbour Trustees (1903), 5 Sess. Cas. at 680 (Scot. CS), especially 691; Lord Advocate v. Balfour, [1907] Sess. Cas. 1360, especially 1368 (Scot. CS). For an argument that the nature of Mikmaw landholding prevented the Crown from acquiring underlying title to lands in the Maritimes, see J.Y. Henderson, "Mikmaw Tenure in Atlantic Canada" (1995) 18 Dalhousie L.J. 196.

s8 Note that in Adams, supra note 10 at 18 (para. 45), and Côté, supra note 11 at 50 (para. 58), Lamer C.J.C. seems to have qualified the time frame by saying that, in the regions in question, the time of contact was "the arrival of Samuel de Champlain in 1603, when the French began to assume effective control over the territories of New France" (Côté, ibid. (para. 58)). This implies that earlier European contacts that did not result in actual colonization, such as Jacques Cartier's 1534-36 visits, would not be appropriate times for applying the "integral to the distinctive culture" test. 
Crown allegedly acquired sovereignty by settlement, ${ }^{60}$ this would be a striking departure from judicial precedent and legal principle. ${ }^{61}$ If Aboriginal title is indeed an interest in land, the relevant question should be whether that title existed when the Crown effectively acquired sovereignty, ${ }^{62}$ because it is at that moment that it must be determined whether the Crown acquired an absolute or merely an underlying title.

We therefore need to ask whether Lamer C.J.C.'s explanation for using time of contact justifies application of that time frame to Aboriginal title. We have seen that he said courts must look to the pre-contact period in identifying Aboriginal rights "[b]ecause it is the fact that distinctive Aboriginal societies lived on the land prior to the arrival of Europeans that underlies the Aboriginal rights protected by s.35(1)."163 He continued:

The fact that the doctrine of Aboriginal rights functions to reconcile the existence of preexisting Aboriginal societies with the sovereignty of the Crown does not alter this position. Although it is the sovereignty of the Crown that the pre-existing Aboriginal societies are being reconciled with, it is to those pre-existing societies that the court must look in defining Aboriginal rights. It is not the fact that Aboriginal societies existed prior to Crown sovereignty that is relevant; it is the fact that they existed prior to the arrival of Europeans in North America. As such, the relevant time period is the period prior to the arrival of Europeans, not the period prior to the assertion of sovereignty by the Crown..$^{\text {At }}$

With all due respect, these passages declare that the pre-contact period applies without really explaining why. The fact is that the Aboriginal peoples lived on the land as preexisting societies at the time of acquisition of sovereignty as well as prior to contact.

60 Settlement is the way an original title to territory could be acquired in British Imperial law, and can be contrasted with conquest and cession, which were ways of acquiring a derivative title: see generally Common Law Aboriginal Title, supra note 35 at 108-33. On the parts of Canada that were allegedly acquired by the Crown by settlement, see ibid. at 267-69. For a critique of the applicability of the settlement concept to territories that were occupied by Aboriginal peoples, see $M$. Asch \& $\mathbf{P}$. Macklem, "Aboriginal Rights and Canadian Sovereignty: An Essay on R. v. Sparrow" (1991) 29 Alta. L. Rev. 498.

61 See Common Law Aboriginal Title, supra note 35, where an examination of various former British colonies revealed that in places as diverse as Ireland, the Gold Coast (Ghana), Sierra Leone, India, British Honduras (Belize), Pitcaim Island and elsewhere the inhabitants who either had land rights under local law or were in occupation of lands at the time the Crown acquired sovereignty had title to those lands as against the Crown. Australia has since been added to this list by the decision of the High Court in Mabo, supra note 35.

62 The time when the Crown acquired sovereignty is a matter of debate in some parts of Canada: e.g. see K. McNeil, “Aboriginal Nations and Quebec's Boundaries: Canada Couldn't Give What It Didn't Have" in D. Drache \& R. Perin, eds., Negotiating with a Sovereign Quebec (Toronto: Lorimer, 1992) 107; M.L. Ng, Convenient Illusions: A Consideration of Sovereignty and the Aboriginal Right of SelfGovernment (LL.M. Thesis, York University, 1994) at 2-69.

63 Van der Peet, supra note 2 at 205 (para. 60).

64 Ibid. at 205 (para. 61) [emphasis in original]. Note that, on the same page (para. 62), Lamer C.J.C. went on to caution courts against applying impossible standards of proof of pre-contact practices, customs and traditions: "The evidence relied upon by the applicant and the courts may relate to Aboriginal practices, customs and traditions post-contact; it simply needs to be directed at demonstrating which aspects of the Aboriginal community and society have their origins pre-contact." See also Adams, supra note 10 at 18-19 (para. 46). 
Prior to acquisition of sovereignty, the common law would not have applied and the Crown would have had no rights in North America. So why is pre-contact, and not the time of acquisition of sovereignty, the relevant period?

For the answer to this question, one must look elsewhere in Lamer C.J.C.'s judgment in Van der Peet. In the introduction to his analysis, he said this:

The task of this Court is to define Aboriginal rights in a manner which recognizes that Aboriginal rights are rights but which does so without losing sight of the fact that they are rights held by Aboriginal people because they are Aboriginal. The Court must neither lose sight of the generalized constitutional status of what s.35(1) protects, nor can it ignore the necessary specificity which comes from granting special constitutional protection to one part of Canadian society. The Court must define the scope of s.35(1) in a way which captures both the Aboriginal and the rights in Aboriginal rights. ${ }^{.5}$

Lamer C.J.C. was obviously concerned about one segment of Canadian society having constitutional protection for rights not enjoyed by all Canadians. ${ }^{66}$ In my opinion, this concern prompted him to limit those rights as much as possible, and one way of accomplishing that was to define those rights in terms of pre-contact practices, customs and traditions. In doing so, he adopted a narrow, time-orientated conception of what "Aboriginal" means in the context of s. 35(1), so that it includes only those aspects of Aboriginal societies that pre-dated and therefore did not arise as a result of contact with Europeans. ${ }^{67} \mathrm{He}$ wrote:

If the practice, custom or tradition was an integral part of the Aboriginal community's culture prior to contact with Europeans, the fact that that practice, custom or tradition continued after the arrival of Europeans, and adapted in response to their arrival, is not relevant to determination of the claim; European arrival and influence cannot be used to deprive an Aboriginal group of an otherwise valid claim to an Aboriginal right. On the other hand, where the practice, custom or tradition arose solely as a response to European influences then that practice, custom or tradition will not meet the standard for recognition of an Aboriginal right. ${ }^{68}$

6s Van der Peet, ibid. at 190 (para. 20) [emphasis in original].

66 For answers to this concern, see P. Macklem, "Distributing Sovereignty: Indian Nations and Equality of Peoples" (1993) 45 Stan. L. Rev. 1311.

67 One has to wonder how this definition takes account of Aboriginal perspectives, as it should according to Lamer C.J.C.'s own directions: see text accompanying notes 22-24, supra. I doubt that any Aboriginal people would accept a static, historically-based conception of what "Aboriginal" means: for one Aboriginal perspective on this, see Borrows, supra note 7, especially at 28-29. Moreover, in Sparrow, supra note 30, Dickson C.J.C. and La Forest J. said in reference to s. 35(1) that "it is clear that a generous, liberal interpretation of the words in the constitutional provision is demanded." Lamer C.J.C. quoted and emphasized these words in Van der Peet, supra note 2 at 191 (para. 23), and added at 192 (para. 25): "The fiduciary relationship of the Crown and Aboriginal peoples also means that where there is any doubt or ambiguity with regards to what falls within the scope and definition of s. 35(1), such doubt or ambiguity must be resolved in favour of Aboriginal peoples." Where is the generous, liberal interpretation, and how is doubt or ambiguity resolved in favour of Aboriginal peoples, in Lamer C.J.C.'s definition of "Aboriginal"?

Van der Peet, supra note 2 at 209-10 (para. 73). 
For Lamer C.J.C., adaptions made to deal with the changing circumstances which necessarily resulted from the arrival of Europeans in North America would only be Aboriginal if there was sufficient continuity with pre-contact practices, customs and traditions. ${ }^{69}$ However, he did not specify the extent to which adaptions could be made without losing the requisite continuity.

So how might the pre-contact time frame for the existence of Aboriginal rights be applied to Aboriginal title? Apparently, it would have to be shown that, prior to European contact, the Aboriginal people in question occupied and used the claimed land in ways sufficient to establish title to the land. ${ }^{70}$ If their occupation and use of that land arose post-contact as a result of European influences, whether before or after acquisition of sovereignty by the Crown, they might not have Aboriginal title." Moreover, Aboriginal title might also be denied them if they used the lands pre-contact, but their occupation and use only became sufficient for Aboriginal title as a result of European influences. In that situation, the validity of their claim would seem to depend on whether there was adequate continuity between their pre- and post-contact uses. If not, then according to Lamer C.J.C.'s conception of "Aboriginal," their occupation and use would not meet the Aboriginal aspect of Aboriginal title.

In my view, it makes no sense to deny Aboriginal people title because they happened to shift their occupation and use of land from one area to another as a result of European influences, at least if that occurred prior to acquisition of Crown sovereignty. ${ }^{72}$ The Crown would have no right whatsoever to those lands prior to acquisition of sovereignty, and could not have prevented the Aboriginal people from acquiring a valid title by occupation and use. Nor would that occupation and use be any less "Aboriginal" just because it resulted from European contact, as the Aboriginal people would have made the move of their own volition and in accordance with their own needs, prior to any European assertion of control or jurisdiction over them. Moreover, while the arrival of Europeans in North America did cause significant Aboriginal population shifts, ${ }^{73}$ those relocations were generally ignored by the representatives of the Crown when they signed land surrender treaties with the Aboriginal peoples. ${ }^{74}$ Attempting to ascertain whether the Aboriginal participants in the treaty process had been in occupation at the time of contact would have made the

69 Ibid. at 206 (para. 64).

7o See text accompanying notes $37-47$, supra.

7 See text accompanying note 19 , supra.

72 Recall that Lamer C.J.C. touched on this issue and left it undecided in Adams, supra note 10 at 12 (para. 28): see text accompanying note 19, supra.

73 E.g. see D.G. Mandelbaum, The Plains Cree: An Ethnographic, Historical and Comparative Study (Regina: Canadian Plains Research Center, University of Regina, 1979) at 15-49; H. Hornbeck Tanner, ed., Allas of Great Lakes Indian History (Norman: University of Oklahoma Press, 1987); R.C. Harris, ed., Historical Atlas of Canada, vol. 1 (Toronto: University of Toronto Press, 1987), especially Plates $33,35,69$.

14 The treaty commissioners entered into the treaties with the Aboriginal peoples who were in occupation at the time, without inquiring whether they had been there prior to European contact or even Crown sovereignty: e.g. see A. Morris, The Treaties of Canada with the Indians of Manitoba and the North-West Territories (Toronto: Belfords, Clarke and Co., 1880) [hereinafter The Treaties of Canada]. 
process unworkable. ${ }^{75}$ Further, if one Aboriginal group had title and subsequently transferred it to or was displaced by another group, the latter group should have acquired an Aboriginal title of its own, even if that occurred after contact or acquisition of Crown sovereignty. ${ }^{76}$

Where an Aboriginal people's use of specific land only became sufficient for them to have the occupation necessary for Aboriginal title as a result of European influences (if that ever happened ${ }^{77}$ ), I still think that Lamer C.J.C.'s time frame for establishing Aboriginal rights would be inapplicable to their Aboriginal title claim. As discussed above, where an interest in land is concerned the time for determining the existence of that interest as against the Crown is the moment of acquisition of sovereignty. ${ }^{78}$ Where an Aboriginal people occupied and used specific lands at that time (whether as a result of European influences or not), then in accordance with common law principles and authorities their occupation and use would give them an interest in those lands and prevent the Crown from acquiring more than an underlying title. ${ }^{79}$ To deny that interest in situations where their occupation was influenced by European contact and therefore not "Aboriginal" would be to disregard established legal doctrine and rely instead on a questionable, time-orientated judicial conception of Aboriginality. In my opinion, that would overlook both the common law and Aboriginal perspectives that Lamer C.J.C. said have to be taken into account in identifying Aboriginal rights, and would not be an appropriate way to develop the jurisprudence necessary to clarify the law of Aboriginal title.

75 See B. Slattery, Ancestral Lands, Alien Laws: Judicial Perspectives on Aboriginal Title, (Studies in Aboriginal Rights No. 2), (Saskatoon: University of Saskatchewan Native Law Centre, 1983) at 3435.

75 See Slattery, supra note 54 at 741-43; The Queen v. Symonds (1847), [1840-1932] N.Z.P.C.C. 387 at 391, Chapman J. American courts have accepted that Indian title could be acquired after acquisition of sovereignty by a European power or the United States. In Sac and Fox Tribe, supra note 47 at $998-99$, Skelton J. wrote:

It is a matter of common knowledge that in the course of years, and especially during the early years of the United States, the use and occupancy of land by Indian tribes changed continuously. New tribes would appear and old ones would disappear or move on to new territories. Sometimes land of one tribe would be exchanged for that of another, or one tribe would acquire the land of another as the result of an Indian war or by right of conquest.... It would not be in accordance with facts nor history to freeze all Indian titles as of the date of the discovery of America, nor with our own Declaration of Independence in 1776. We know that there was considerable change in such titles after these dates. Consequently, it is not possible to fix any cutoff date for the establishment of Indian title, except the date the Indians lose the land through treaty or otherwise.

See also Turtle Mountain Band v. United States, 490 F. $2 d 935$ at $941-42$ (U.S. Ct. Cl. 1974)

[hereinafter Turlle Mountain Band].

$n$ In my view, it is very doubtful that any Aboriginal people lacked the requisite degree of occupation and use for them to have Aboriginal title prior to contact: see text accompanying notes $37-47$, supra. See text accompanying notes 56-62, supra. 


\section{B. Content of aboriginal Title}

In our discussion so far, we have seen that the Supreme Court has intimated that it will apply the "integral to the distinctive culture" test to an Aboriginal title claim to determine whether the claimants' connection with the land was sufficient to make out their claim of title. ${ }^{80}$ However, the way the test might be applied in that context remains uncertain. Moreover, it is unclear whether the test will only apply to the issue of the existence of Aboriginal title, or whether it will also be used to define the title's content once its existence has been established. In my opinion, if the test is applied to an Aboriginal title claim its application should be limited to the first issue - it should not be used to define the content of an established Aboriginal title.

The content of Aboriginal title should be determined by the fact that the Aboriginal people in question were in occupation of the land as a distinctive society at the relevant time, ${ }^{81}$ not by the specific uses they happened to be making of the land at that particular historical moment. ${ }^{82}$ As discussed above, those uses are relevant to determining whether the Aboriginal people were in occupation, but that is as far as their relevance extends.

Taking the perspectives of the Aboriginal peoples into account, as Lamer C.J.C. said we must, ${ }^{83}$ I think it is safe to assume that no Aboriginal people would ever have regarded their entitlement to land as limited to the uses they made of it at a particular time. ${ }^{84}$ Every society changes and adapts as new circumstances arise and technological innovations are made, and changes in land use are inevitably a part of this dynamic process. Societies that are unwilling or unable to adapt are unlikely to survive. Denying Aboriginal peoples the opportunity to change their land uses in response to the massive impact European colonization had on their ways of life would have condemned their societies to extinction. Moreover, government policy in Canada encouraged the Aboriginal peoples to change their uses of the land so that they would continue to be self-sufficient. As Professor Brian Slattery has written, when officials urged certain Aboriginal groups to abandon their traditional ways of life and "to take up farming, they were not sanctioning an unlawful user of land." 85

So taking into account Aboriginal perspectives, the dynamic nature of human societies, and government policy, an approach that limits the content of Aboriginal title

Compare Delgamukw, supra note 54. For critical commentary on the aspect of the decision relating to the content of Aboriginal title, see K. McNeil, "The Meaning of Aboriginal Title" in M. Asch, ed., Aboriginal and Treaty Rights in Canada: Essays on Law, Equality and Respect for Difference (Vancouver: University of British Columbia Press, 1997) 135 (hereinater "The Meaning of Aboriginal Title"].

3) See text accompanying notes 22-24, supra.

34 Moreover, whether one adopts European contact, Crown acquisition of sovereignty, or some other historical moment as the relevant time, from an Aboriginal perspective it would no doubt be arbitrary.

ss Slattery, supra note 54 at 747 . Slattery, of course, was referring to Aboriginal peoples who did not engage in agriculture prior to European colonization. 
to land uses at some precise historical moment appears to be fundamentally flawed. Professor Slattery made this point vividly when he wrote that, on the supposition that Aboriginal title is limited to customary practices followed at some distant historical period,

aboriginal title is like an historical diorama in a museum. Here a smiling native strips birchbark from a tree, there a warrior aims bow and arrow at a mildewed deer, while in the corner a youngster plucks plastic blueberries from a withered bush. We must, of course, disregard the next display, where Indians under the stern but kindly eye of a black-robed missionary plant their first crop of corn. Agriculture, if not practiced aboriginally, is forbidden. The difficulty with this conception, of course, is that native people are not waxen figures on display for tourists, but living people who depend on the land for their livelihood. Any rule that would hold them in permanent bondage to ancient practices must be regarded with scepticism. ${ }^{\text {86 }}$

In addition, limiting the content of Aboriginal title to past uses violates common law principles and accepted norms of non-discrimination, and conflicts with established judicial precedents.

\section{Common Law Principles and Non-Discrimination}

In the common law, possession is the root of all titles to land. ${ }^{87}$ Even the Crown's title in England, which by a legal fiction is deemed to have preceded all other land titles, is taken to have arisen from the Crown's supposed possession of the whole realm as "universal occupant." 88 Possession is established by proof of occupation, which depends on evidence of sufficient acts of use and control in relation to the land ${ }^{89}$ Invariably, evidence of use relates solely to the issue of whether the person claiming title has the requisite possession. Once possession has been established the possessor has a title, the nature of which is in no way dependent on the acts of use relied on to prove it. ${ }^{90}$

A title rooted in possession entitles the possessor to an interest in the land. The kind of interest acquired depends on the nature of the interest available for acquisition at the time possession was taken. In a hypothetical situation where the land was

80 Ibid. at 746.

87 The King v. Lord Yarborough (1828), 2 Bli. (N.S.) 147 at 159. See generally Common Law Aboriginal Title, supra note 35 at 6-78.

88 M. Bacon, A New Abridgement of the Law, vol. 8 (Philadelphia: T \& J.W. Johnson, 1854) at 13. See also Anonymous, Considerations on the Law of Forfeiture, for High Treason, 4th ed. (London: J. Williams, 1775) 64-65; J. Chitty, A Treatise on the Law of the Prerogatives of the Crown (London: Joseph Butterworth and Son, 1820) 211; W. Blackstone, Commentaries on the Laws of England, vol. 2, 16th ed. (London: T. Cadell and J. Butterworth and Son, 1825) at 51.

89 See works cited in note 41 , supra.

so See authorities cited in notes $42-44$, supra. 
unowned by anyone, ${ }^{91}$ the possessor would have acquired the greatest interest possible, which in the common law system of estates is a fee simple interest. ${ }^{92}$ Where an estate pur autre vie became vacant as a result of the death of the life tenant prior to the death of the cestui que vie, at common law the first person to take possession would have acquired the pur autre vie estate as occupant. ${ }^{93}$ Where a disseisor or adverse possessor wrongfully took possession, whether from a leaseholder or freeholder, the possessor would have acquired a fee simple, albeit tortious. ${ }^{94}$ In each of these circumstances, the nature of the interest acquired depends on circumstances which have nothing to do with the nature of the acts in relation to the land that would have been relied upon to establish the possession. Once that interest has been acquired, the possessor is entitled to put the land to any use, subject to relevant common law limitations such as those imposed by the law of nuisance, and to legislative restraints created by zoning laws, building codes, and the like. Moreover, as possession of the surface also entails possession of the subsurface (unless someone else has possession thereof), ${ }^{95}$ the possessor would generally be entitled to mineral rights. ${ }^{96}$

So from a common law perspective, sufficient evidence of occupation and use will establish an entitlement to an interest in land, just as sufficient evidence of occupation and use will establish an entitlement to Aboriginal title. At common law, an interest acquired by possession is not limited to the uses relied upon to establish the possession. So is there any reason why Aboriginal title should be so limited? Taking the Aboriginal perspective into account would be unlikely to provide such a reason, as no doubt Aboriginal people generally would not think that their entitlement to use the land would ever have been limited to the uses they happened to make of it at any particular time. Like possessors of land in England, they would probably think that,

II I say "hypothetical" because the common law doctrine of tenures probably makes it impossible for land to be unowned, as in the absence of a fee simple or other tenancy, the land will be deemed to be owned by the Crown. However, mere lack of proof of a tenancy is not sufficient for the Crown to have a valid claim: see Bristow v. Cormican, supra note 43.

92 This may have occurred in British Honduras (now Belize) and on Pitcairn Island: see Common Law Aboriginal Title, supra note 35 at 141-57.

93 See Blackstone, supra note 88, vol. 2 at 259-60; Bacon, supra note 88, "Estate for Life and Occupancy" B.1; H.W. Challis, The Law of Real Property (London: Reeves and Turner, 1885) at 287-89.

See Leigh v. Hudson (1565), 2 Dyer 238b; Elvis v. Archbishop of York (1619), Hob. 315 at 323; Wheeler v. Baldwin (1934), 52 C.L.R. 609 at 632 (H.C. Aust.). However, there may be an exception where the person dispossessed was a leaseholder and the dispossessor claimed the leasehold rather than the fee simple: see Mayor of Norwich v. Johnson (1681), 3 Lev. 35.

See Lewis v. Branthwaite (1831), 2 B. \& Ad. 437; Keyse v. Powell (1853), 2 El. \& Bl. 132 at 14445. In Rowbotham v. Wilson (1860), 8 H.L.C. 348 at 360, Lord Wensleydale said that "prima facie the owner of the surface is entitled to the surface itself and all below ex jure naturae."

* However, in the case of a pur autre vie estate acquired by occupancy, the law of waste would have prevented the occupant from opening new mines: see Worcester's Case (1605), 6 Co. Rep. 37a; Campbell v. Wardlaw (1883), 8 App. Cas. 641 (H.L.); Halsbury's Laws of England, vol. 42, 4th ed. (London: Butterworths, 1983) at 530 (para. 993). 
subject to their own customary laws, ${ }^{97}$ they could make any use of it that met their current needs and aspirations.

It will be recalled that in Van der Peet Lamer C.J.C. said that Aboriginal rights should be defined "in a manner which recognizes that Aboriginal rights are rights but which does so without losing sight of the fact that they are rights held by Aboriginal people because they are Aboriginal." 98 In my view, this Aboriginal aspect would be fulfilled in the context of Aboriginal title by a requirement that the occupation and use relied on to establish the title involved a connection with the land that was integral to the distinctive culture of the Aboriginal people in question. This approach would be consistent with the common law principles discussed above, and take account of the Aboriginal perspective, but it would also give coherence to the development of the law of Aboriginal rights. Adams and Côté contributed to this development by informing us that free-standing rights such as a right to hunt or fish can exist independently of Aboriginal title. This must mean that free-standing rights and Aboriginal title are conceptually different. The distinction that appears from Adams in particular is that free-standing rights involve activities on the land that are integral to the Aboriginal people's distinctive culture, whereas Aboriginal title involves a connection with the land itself that meets the integral test. Aboriginal title therefore must be more than a collection of rights to pursue activities on the land that could exist separately as freestanding rights. Like a title acquired by possession at common law, it entails an interest in land that is not limited to specific uses, but rather entitles the Aboriginal title holders to use the land in ways that meet their current needs and aspirations. They would therefore be able to practice agriculture, engage in lumbering, extract minerals, and so on, regardless of whether they had done so in the past.

This analysis of the content of Aboriginal title conforms with accepted standards of non-discrimination because it accords Aboriginal peoples an interest in land based on their occupation and use that is equivalent to the interest accorded to non-Aboriginal people on the same basis. While Aboriginal title probably is not the same as a fee simple estate, ${ }^{99}$ it is equivalent in the sense that it is perpetual, enduring for as long as the Aboriginal people in question continue to exist, or until it is surrendered to the Crown or otherwise validly extinguished. ${ }^{100}$ If the uses Aboriginal people can make

97 Like common law and statute law, those laws would not be fixed at any particular point in time, but could and would change to meet the changing circumstances encountered by their societies. In Hineiti Rirerire Arani v. Public Trustee, [1920] A.C. 198 at 204-205 (P.C.) and Mabo, supra note 35 at 61, Brennan J., at 110, Deane and Gaudron JJ., it was accepted that changes in the customary law of indigenous peoples might occur even after the Crown acquired sovereignty over their territories.

Van der Peet, supra note 2 at 190 (para. 20).

99 See Guerin, supra note 1. As Dickson J. said in that case at 382, what makes Aboriginal title unique is that it is inalienable except by surrender to the Crown, and that upon surrender there is a fiduciary duty on the Crown to deal with the land on behalf of the Aboriginal people who executed the surrender. While those features led Dickson J. to describe Aboriginal title as sui generis, they do not relate to and should not detract from the content of that title: see "The Meaning of Aboriginal Title," supra note 82 at 142-44, and note 112 , infra.

100 Note that Aboriginal title could be extinguished by clear and plain federal legislation prior to the enactment of s. 35(1) of the Constitution Act, 1982, but since then that is no longer possible: see Sparrow, supra note 30 at 174-75; Van der Peet, supra note 2 at 193 (para. 28). 
of their land are limited to historic uses while the uses a fee simple tenant can make are not, that is discriminatory. This is vividly illustrated in a situation where an adverse possessor wrongfully takes possession of someone else's land and remains there for the statutory limitation period, which in some Canadian provinces is only ten years. That wrongdoer will have a fee simple estate acquired through possession, ${ }^{101}$ entitling him or her to make any use of the land permitted by law, regardless of the nature of the acts relied on to establish the adverse possession. Moreover, those acts may be no different from, and could even be less extensive than, acts of use relied on to establish Aboriginal title. ${ }^{102}$ Any legal system that would accord a greater interest in land to a wrongdoer, after just ten years adverse possession, than it would to Aboriginal peoples who have rightfully occupied and used lands for hundreds or even thousands of years, is not entitled to respect. As the Supreme Court has rejected the application of discriminatory doctrines where the existence of Aboriginal title is concerned, ${ }^{103}$ one would expect it to take a non-discriminatory approach to the issue of the content of Aboriginal title as well. There are indications in the case law, supported by decisions in other jurisdictions, that the Court will take such an approach.

\section{Judicial Precedents}

In Australia, the leading case of Mabo v. Queensland [No. 2] established that Native title (as Aboriginal title, with an important distinction to be discussed below, is generally called there) is an interest in land recognized by the common law from the time of acquisition of sovereignty by the Crown. ${ }^{104}$ The case involved a claim to an existing Native title by the Meriam people, an indigenous community inhabiting the Murray Islands in the Torres Strait off Cape York in northern Queensland. Writing the principal majority judgment, Brennan J. said this about the source and nature of Native title generally:

Native title has its origin in and is given its content by the traditional laws acknowledged by and the traditional customs observed by the indigenous inhabitants of a territory. The nature

101 The adverse possessor's title arises from his or her possession, not from a legislative conveyance, because all the statute does is extinguish the rights and title of the dispossessed fee simple tenant when the limitation period expires, thereby making the wrongdoer's title unchallengeable: see Tichborne v. Weir (1892), 67 L.T. 735; In re Atkinson and Horsell's Contract, [1912] 2 Ch. 1 at 9, 17; Fairweather v. St. Marylebone Property Co., [1963] A.C. 510, especially 535 (H.L.).

102 E.g. see Kirby, supra note 42 (payment of taxes on "wild" land with no actual occupation or use); Cadija Umma, supra note 44 (cutting wild grass); Red House Farms, supra note 43 (hunting: see text accompanying note 43 , supra).

103

See Côté, supra note 11 at $48-49$ (para. 53), where Lamer C.J.C. said that acceptance of the argument that no Aboriginal rights exist in the parts of Canada originally colonized by France would risk "undermining the very purpose of s. 35(1) [of the Constitution Act, 1982] by perpetuating the historical injustice suffered by Aboriginal peoples at the hands of colonizers who failed to respect the distinctive cultures of pre-existing Aboriginal societies." He supported his reasons for rejecting this argument by quoting the following passage from Brennan J.'s judgment in Mabo, supra note 35 at 42: "Whatever the justification advanced in earlier days for refusing to recognize the rights and interests in land of the indigenous inhabitants of settled colonies, an unjust and discriminatory doctrine of that kind can no longer be accepted."

tot Mabo, ibid., especially per Brennan J. at 38-52, Toohey J. at 180-92, 205-14; compare per Deane and Gaudron JJ. at 81-95, 109-10. 
and incidents of native title must be ascertained as a matter of fact by reference to those laws and customs. ${ }^{105}$

In Van der Peet, Lamer C.J.C. quoted this passage and commented as follows:

This position is the same as that being adopted here. "[T]raditional laws" and "traditional customs" are those things passed down, and arising, from the pre-existing culture and customs of Aboriginal peoples.... To base Aboriginal title in traditional laws and customs, as was done in Mabo, is, therefore, to base that title in the pre-existing societies of Aboriginal peoples. This is the same basis as that asserted here for Aboriginal rights. ${ }^{105}$

Taken alone, the above passage from Brennan J.'s judgment and Lamer C.J.C.'s comments on it could leave the impression that traditional laws and customs are all that matter where the source and content of Native or Aboriginal title are concerned. However, Lamer C.J.C. linked both the identification and definition of Aboriginal rights, including Aboriginal title, to occupation of land.$^{107}$ In Mabo, a similar kind of dual approach to Native title is apparent. Brennan J. wrote:

If it be necessary to categorize an interest in land as proprietary in order that it survive a change in sovereignty, the interest possessed by a community that is in exclusive possession of land falls into that category. Whether or not land is owned by individual members of a community, a community which asserts and asserts effectively that none but its members has any right to occupy or use the land has an interest in the land that must be proprietary in nature: there is no other proprietor.... The ownership of land within a territory in the exclusive occupation of a people must be vested in that people: land is susceptible of ownership, and there are no other owners. ${ }^{103}$

What then is the relationship between this proprietary interest arising from exclusive occupation and the traditional laws and customs of the community? Brennan J. provided some clarification of this relationship in the following passage:

Where a proprietary title capable of recognition by the common law is found to have been possessed by a community in occupation of a territory, there is no reason why that title should not be recognized as a burden on the Crown's radical title when the Crown acquires sovereignty over that territory. The fact that individual members of the community ... enjoy only usufructuary rights that are not proprietary in nature is no impediment to the recognition of a proprietary community title... That being so, there is no impediment to the recognition of individual non-proprietary rights that are derived from the community's laws and customs and are dependent on the community title. A fortiori, there can be no impediment to the recognition of individual proprietary rights. ${ }^{109}$

Ibid. at 58; see also per Deane and Gaudron JJ. at 87-88, 110; compare per Toohey J., especially at $187-92$. 207-14. 
The composite picture that emerges from Brennan J.'s judgment is of an indigenous community, with laws and customs governing land rights and interests, that was in exclusive occupation of a territory at the time the Crown acquired sovereignty. Regardless of the nature of the rights and interests stemming from those internal laws and customs, as against the Crown, the community's exclusive occupation of the territory would have given it a proprietary title akin to ownership. Upon acquisition of sovereignty, the common law would have given the Crown a radical title, but in those circumstances this underlying title would be "merely a logical postulate required to support the doctrine of tenure ... and to support the plenary title of the Crown" when the Native title was validly extinguished. ${ }^{110}$

So where an indigenous community was in exclusive occupation, ${ }^{\prime \prime \prime}$ its title would arise from that occupation, and would be much the same as ownership, which must mean that it is equivalent to a fee simple. ${ }^{112}$ Traditional laws and customs would apply internally to determine the nature of the rights and interests of members of the

130 Ibid. at 50; see also per Deane and Gaudron JJ. at 80-81, 86-87, Toohey J. at 180-82.

i1' The exclusivity aspect does not mean that two or more indigenous communities could not be coowners, as long as they were not disputing the occupation. In the United States, it has been held that two or more Indian groups who jointly and amicably occupied the same lands to the exclusion of others would have original Indian title: see Turtle Mountain Band, supra note 76 at 944; United States v. Pueblo of San Ildefonso, 513 F. 2d 1383 at 1394-95 (U.S. Ct. Cl. 1975); Strong v. United States, 518 F. 2d 556 at $561-62$ (U.S. Ct. Cl. 1975), cert. denied 423 U.S. 1015 (1975). Referring to United States v. Santa Fe Pacific Railroad Co., supra note 47 at 345, Toohey J., in his concurring judgment in Mabo, supra note 35 at 189-90, said this:

This principle of exclusive occupancy is justified in so far as it precludes indiscriminate ranging over land but it is difficult to see the basis for the rule if it precludes title merely on the ground that more than one group utilizes land. Either each smaller group could be said to have title, comprising the right to shared use of land in accordance with traditional use; or traditional title vests in the larger "society" comprising all the rightful occupiers.

112 See also Mabo, ibid. at 75, where Brennan J. observed:

As the Crown holds the radical title to the Murray Islands and as native title is not a title created by grant nor is it a common law tenure, it may be confusing to describe the title of the Meriam people as conferring "ownership," a term which connotes an estate in fee simple or at least an estate of freehold. Nevertheless, it is right to say that their native title is effective as against the State of Queensland and as against the whole world unless the State, in valid exercise of its legislative or executive power, extinguishes the title.

See also per Toohey J. at 207-14, especially his conclusion at 214 that it would be "no more beneficial for the plaintiffs" to have possessory title to a fee simple estate than to have traditional title (as he called Native title); ergo, Native title is just as good as a fee simple (this is confirmed at $\mathbf{2 1 6}$ by his description of the traditional title of the Meriam people to the Murray Islands as "their rights to possession, occupation, use and enjoyment of the Islands..."). While it is true that Native title, unlike most estates in fee simple, is inalienable other than by surrender to the Crown, Brennan J. wrote at 51 that "[i]t would be wrong, in my opinion, to point to the inalienability of land by that [an indigenous] community and, by importing definitions of 'property' which require alienability under the municipal law of our society, to deny that the indigenous people owned their land" [footnote omitted]. Compare per Deane and Gaudron JJ. at 88-90, critiqued in "Racial Discrimination," supra note 54 at 204-208. See also United States v. Paine Lumber Company, 206 U.S. 467 at 473 (1907), where McKenna J., delivering the opinion of the United States Supreme Court, said in reference to Indian title: "The restraint upon alienation must not be exaggerated. It does not of itself debase the right below a fee simple." For discussion of the issue of inalienability, and for authority that not all fee simple estates are alienable, see Common Law Aboriginal Tille, supra note 35 at 221-35. 
community, which may or may not be proprietary, but would not operate externally to define or limit the community's title as against the Crown or third parties. ${ }^{113}$ That this is what Brennan J. meant when he said that Native title is given its content by traditional laws and customs is apparent from his acceptance of the dynamic nature of indigenous legal systems. He wrote:

\begin{abstract}
Of course in time the laws and customs of any people will change and the rights and interests of the members of the people among themselves will change too. But so long as the people remain as an identifiable community, the members of whom are identified by one another as members of that community living under its laws and customs, the communal native title survives to be enjoyed by the members according to the rights and interests to which they are respectively entilled under the traditionally based laws and customs, as currently acknowledged and observed."14
\end{abstract}

From this passage, it appears that the communal Native title will be maintained by the continuance of an identifiable community and remain constant, regardless of changes to rights and interests within the community made by modifications to the traditional laws and customs. If the nature of Native title itself could be altered by modifications to those laws and customs, the radical title of the Crown would be affected as well. As Brennan J. upheld the sovereignty of the Crown and its authority to extinguish Native title, ${ }^{115}$ he could not have intended to recognize a contravening power permitting indigenous communities to modify the Crown's underlying title.

The interpretation of Brennan J.'s judgment presented above is also consistent with the formal order the High Court made in Mabo - indeed, if the nature of the Meriam people's title as against the Crown really depended on their traditional laws and customs, the order would make no sense. That order, which in this respect corresponds with the declaration Brennan J. proposed, declared in part "that the Meriam people are entitled as against the whole world to possession, occupation, use and enjoyment of the lands of the Murray Islands." 116 Significantly, the order, which was a declaration of "the native communal title of the Meriam people,"117 was made even though Moynihan J., the finder of fact in the case, had found no such communal title in Meriam law or custom. According to Brennan J., Moynihan J. had "found that there was apparently no concept of public or general community ownership among the people of Murray Island, all the land of Murray Island being regarded as belonging to individuals or groups."118 So the communal native title of the Meriam people which

113 However, the existence of those laws and customs would probably support the assertion of the indigenous people that they were in occupation as a community: see quotation accompanying note 108, supra. See also Mabo, ibid. per Toohey J., especially 187-92, 206-14, 216.

114 Ibid. at 61 [emphasis added]; see also per Deane and Gaudron JJ. at 110, Toohey J. at 192.

IIs Ibid. at 31-34, 63-71. For a critique of Brennan J.'s position on extinguishment, see "Racial Discrimination," supra note 54 at 190-203.

116 Mabo, ibid. at 217 [emphasis omitted].

117 Ibid. at 75, Brennan J.

118 Ibid. at 22, Brennan J. See also per Toohey J. at 191, where he observed that "the findings of Moynihan J. do not allow the articulation of a precise set of rules," but went on to conclude that that did not matter because "the particular nature of the rules which govern a society or which describe 
the High Court declared to exist must have originated and derived its content from their exclusive occupation as a community of the Murray Islands, not from their traditional laws or customs. ${ }^{119}$ Those laws and customs would nonetheless be applicable to determine the existence and content of individual and group rights within the Meriam community. ${ }^{120}$

The High Court returned to the issue of Native title recently in Wik Peoples v. Queensland, ${ }^{121}$ where it decided by a majority of four to three that Crown grants of pastoral leases did not necessarily extinguish Native title in Australia. ${ }^{122}$ The majority nonetheless rejected the argument that extinguishment will only occur when there is factual inconsistency between the use a grantee actually makes of the land and the exercise of the Native title rights, and held instead that inconsistency between their legal rights will extinguish, or suspend, the Native title to the extent of the inconsistency. ${ }^{123}$ The majority concluded that it could not decide whether legal inconsistency existed between the pastoral leases in question and the Native title claimed by the Wik and Thayorre peoples in the case, as the existence of that title and the extent of the rights entailed by it had not yet been determined by the trial judge. $^{124}$

However, if Native title amounts to an interest akin to ownership which is equivalent to a fee simple, as Brennan J. apparently concluded in Mabo, then it would include a right of exclusive possession. As we have seen, the High Court in that case declared that the Native title of the Meriam people entitles them to possession as against the whole world, ${ }^{125}$ which means they have a right of exclusive possession. As such a right would no doubt be inconsistent with the rights of pastoral leaseholders, the majority's decision in Wik depends on an assumption that the content of Native title is not necessarily equivalent to a fee simple, and can vary from one indigenous group to another.

its members' relationship with land does not determine the question of traditional land rights."

119 Toohey J.'s judgment contains the clearest articulation of this basis for the declaration in the order: ibid. at $188-92$.

120 Two of the plaintiffs had originally claimed individual or group rights to specific lands on the Islands, but as the factual findings were not sufficient and the action was not constituted in a way that would have permitted the granting of declaratory relief with respect to those claims, "[t]he plaintiffs" statement of claim was then amended to seek declarations relating to the title of the Meriam people": ibid. at 75, Brennan J.

121 Wik Peoples v. Queensland (1996) 141 A.L.R. 129 (H.C. Aust) [hereinafter Wik].

122 For commentary, see R.H. Bartlett, "The Fundamental Significance of Wik v. State of Queensland in the High Court of Australia" [1997] 2 C.N.L.R. 1; K. McNeil, "Co-Existence of Indigenous Rights and Other Interests in Land in Australia and Canada" [1997] 3 C.N.L.R. 1 [hereinafter "Co-Existence of Indigenous Rights"]; and collections of articles in (1997) 4:1 Indigenous Law Bulletin, Special Wik Issue, and (1997) 3:2 University of New South Wales Law Journal FORUM, "Wik. The Aftermath and Implications."

123 See Wik, supra note 121 at 185, Toohey J.; at 193, Gaudron J.; at 233, Gummow J.; at 262, 273-75, 279, Kirby J.; and commentary in "Co-Existence of Indigenous Rights," ibid. The majority left the issue of whether Native title could be suspended for the duration of an inconsistent interest open: see at 188, Toohey J.; at 248, Gummow J.; at 279-86, Kirby J.

124 Ibid., per Toohey J. at 188-90, Gaudron J. at 218-19, Gummow J. at 220-22, Kirby J. at 285-86.

125 See text accompanying note 116, supra. 
Toohey J., whose general conclusions were accepted by the other majority judges in $W_{i k}{ }^{126}$ was explicit in this regard. Quoting from Deane and Gaudron JJ. and his own judgment in Mabo, as well as from Lamer C.J.C.'s judgment in Van der Peet, he wrote:

Inconsistency can only be determined, in the present context, by identifying what native title rights in the system of rights and interests upon which the appellants [the Wik and Thayorre peoples] rely are asserted in relation to the land contained in the pastoral leases. This cannot be done by some general statement; it must "focus specifically on the traditions, customs and practices of the particular Aboriginal group claiming the right". ${ }^{232}$ Those rights are then measured against the rights conferred on the grantees of the pastoral leases; to the extent of any inconsistency the latter prevail. It is apparent that at one end of the spectrum native title rights may "approach the rights flowing from full ownership at common law". ${ }^{233}$ On the other hand they may be an entitlement "to come on to land for ceremonial purposes, all other rights in the land belonging to another group". 234 Clearly there are activities authorised, indeed in some cases required, by the grant of a pastoral lease which are inconsistent with native title rights that answer the description in the penultimate sentence. They may or may not be inconsistent with some more limited right. ${ }^{127}$

It therefore seems that in Australia the Meriam people's entitlement "as against the whole world to possession, occupation, use and enjoyment" ${ }^{28}$ is only one kind of Native title, entailing rights that "approach the rights flowing from full ownership at common law." As we have seen from our discussion of Mabo, a Native title of that sort arises where an indigenous people as a community is in exclusive occupation of their territory at the time of acquisition of sovereignty by the Crown, regardless of their traditional laws and customs. ${ }^{129}$ An indigenous people could nonetheless have a less extensive Native title, if they used land for a specific purpose, such as ceremonial rites, but lacked exclusive occupation because the land was also used by other indigenous peoples. ${ }^{130}$ Relying on Van der Peet, Toohey J. said that their traditions, customs and practices would be relevant in those circumstances. But a less extensive Native title of that sort is really more like what Lamer C.J.C. described in Adams and Côté as a freestanding, site-specific right, that does not necessitate an Aboriginal title to the land itself. There thus appears to be a divergence between the Supreme Court of Canada's conception of Aboriginal title and the High Court of Australia's conception of Native title. For the Supreme Court, Aboriginal title is apparently limited to the kind of title found in Mabo where there is sufficient occupation and use to warrant an entitlement "as against the whole world to possession, occupation, use and enjoyment," whereas

Wik, supra note 121 at $189-90$.

127 Ibid. at 185 (the footnotes in this passage contain these references: ${ }^{232} R$. v. Van der Peet (1996), 137 D.L.R. (4th) 289 at 318, Lamer C.J.C.; ${ }^{233}$ Mabo [No. 2] (1992) 175 C.L.R. 1 at 89, 107 A.L.R. 1 [per Deane and Gaudron JJ.]; ${ }^{234}$ Mabo [No. 2] (1992) 175 C.L.R. 1 at 190, 107 A.L.R. 1 [per Toohey J.]); see also per Gummow J. at 220, Kirby J. at 284. 
for the High Court, Native title also includes more limited site-specific rights such as a right to use land only for ceremonial purposes.

The conclusion that Aboriginal title in Canada amounts to rights approaching full ownership, like the Meriam people were found to have in Mabo, is strongly supported by the decision of Dickson J. (as he then was) in Guerin v. $R^{131}$ While that case involved the Crown's fiduciary duty with respect to reserve lands rather than a claim to Aboriginal title, Dickson J. held that " $[t]$ he fiduciary relationship between the Crown and the Indians has its roots in the concept of aboriginal, native or Indian title."132 The Crown's fiduciary duty arises because, in his words, "the Indian interest in the land is inalienable except upon surrender to the Crown." ${ }^{133}$ Relying on Calder v. Attorney General of British Columbia, ${ }^{134}$ Dickson J. went on to describe Aboriginal title as "a legal right derived from the Indians' historic occupation and possession of their tribal lands." ${ }^{135} \mathrm{He}$ found further authority for this in Marshall C.J.'s decision in Johnson v. $M^{\prime}$ 'Intosh, ${ }^{136}$ particularly in a lengthy quotation containing a passage which he emphasized as follows: "They [the Indians] were admitted to be the rightful occupants of the soil, with a legal as well as just claim to retain possession of it, and to use it according to their own discretion."137 While not quoting from it, Dickson J. also relied on Worcester v. State of Georgia, where Marshall C.J. clarified his position on Indian title by saying that it was "the universal conviction that the Indian nations possessed a full right to the lands they occupied."138

While Guerin involved reserve lands, Dickson J. dealt with the issues of the existence and nature of Indian or Aboriginal title at some length because reserves generally are areas where Aboriginal title has been specifically recognized by treaty or unilateral government action. For that reason, the Indian interest in reserves and Aboriginal title lands is the same. He wrote:

It does not matter, in my opinion, that the present case is concerned with the interest of an Indian Band in a reserve rather than with unrecognized aboriginal title in traditional tribal lands. The Indian interest in the land is the same in both cases: see Attorney-General for Quebec v. Attorney-General for Canada, [1921] 1 A.C. 401, at pp. 410-11 (the Star Chrome case). It is worth noting, however, that the reserve in question here was created out of the ancient tribal territory of the Musqueam Band [on whose behalf the Guerin action was

Guerin, supra note 1. Wilson and Estey JJ. wrote concurring judgments (Estey J. in particular based his judgment on different grounds), but as Dickson $J$. wrote for four members of an eight member bench, his decision is generally regarded as the leading judgment. lbid. at 376.

133 Ibid.

134. Calder, supra note 9.

135 Guerin, supra note 1 at 376.

1368 Wheat. 543 (1823) [hereinafter Johnson].

137 Guerin, supra note 1 at 378, quoting from Johnson, ibid. at 574 [Dickson J.'s emphasis].

138 6 Pet. 515 at 560 (1832). 
brought] by the unilateral action of the Colony of British Columbia, prior to Confederation. ${ }^{139}$

While the Musqueams did not sign a treaty with the Crown providing for the creation of their reserve out of their tribal territory, many Aboriginal peoples in Canada did sign treaties to that effect. In some cases those treaties involved the setting aside of reserves by the Crown after a general surrender of Aboriginal title lands, ${ }^{140}$ while in other cases the reserves were made up of lands excluded from the surrender, where Aboriginal title was retained. ${ }^{141}$ However, that distinction makes no difference insofar as the Indian interest in reserve lands is concerned, as that interest is the same regardless of how the reserve was created. ${ }^{142}$

Since the Indian interest in reserve and Aboriginal title lands is the same, investigation of the nature of the former will assist us in determining the content of Aboriginal title. Both statute and case law reveal that, while Indians do not have a fee simple estate in their reserve lands, ${ }^{143}$ they are entitled to the full use and benefit of those lands, including surface and subsurface resources, regardless of whether they used

139 Guerin, supra note 1 at 379 . In this respect, Dickson J.'s judgment is fully supported by decisions in the United States, where the courts have held that, in valuing Indian land for the purpose of paying compensation, it makes no difference whether the land is held by original Indian title (the common American term for Aboriginal title), or is land specifically reserved by treaty or otherwise; in both cases, the value of the land is the same as it would be if the Indians held the fee simple, and includes the value of both surface and subsurface resources: see United States v. Shoshone Tribe, 304 U.S. 111 at 115-18 (1938) [hereinafter Shoshone Tribe]; United States v. Klamath and Moadoc Tribes, 304 U.S. 119 at 122-23 (1938) [hereinafter Klamath and Moadoc Tribes]; Otoe and Missouria Tribe v. United States, 131 F. Supp. 265 at 288-91 (U.S. Ct. Cl. 1955), cert. denied 350 U.S. 848 (1955) [hereinafter Otoe and Missouria Tribe]; Miami Tribe of Oklahoma v. United States, 175 F. Supp. 926 at 942 (U.S. Ct. Cl. 1959); United States v. Northern Paiute Nation, 393 F. 2 d 786 at 796 (U.S. Ct. Cl. 1968). In Otoe and Missouria Tribe at 290-91, Littleton J. for the Court of Claims expressly rejected the argument that the land be valued in accordance with the use the Indians made of it; instead, appropriate factors to be considered were

the natural resources of the land ceded, including its climate, vegetation, including timber, game and wildlife, mineral resources and whether they are of economic value at the time of cession, or merely of potential value, water power, its then or potential use, markets and transportation - considering the ready markets at that time and the potential market.

In rejecting "the 'subsistence' approach advocated by the Government," at 291 he said: "Values cannot be determined on the basis of berries and wild fruits." See also United States ex rel. Chunie v. Ringrose, 788 F. 2d 638 at 642 (9th Cir. 1986), where Fletcher J. for the Ninth Circuit Court of Appeals wrote: "Aboriginal title entitles the tribes to full use and enjoyment of the surface and mineral estate, and to resources, such as timber, on the land."

140 E.g. see the Numbered Treaties, 1 to 7 of which are reproduced in The Treaties of Canada, supra note 74 at 313-75.

141 E.g. see the Robinson Treaties, ibid. at 302-309.

142 See "The Meaning of Aboriginal Title," supra note 82 at 148-51.

143 See Guerin, supra note 1, especially per Wilson J. at 349. 
those resources prior to the creation of the reserve. ${ }^{144}$ The 1927 Indian Act, for example, defined "reserve" as

any tract or tracts of land set apart by treaty or otherwise for the use or benefit of or granted to a particular band of Indians, of which the legal title is in the Crown, and which remains so set apart and has not been surrendered to the Crown, and includes all the trees, wood, timber, soil, stone, minerals, metals and other valuables thereon or therein. ${ }^{145}$

Assuming that Parliament abided by "the valuable rule never to enact under guise of definition,"146 this would simply have been declaratory of the interest the Indians already had in their reserve lands prior to the definition's enactment. ${ }^{147}$ Moreover, case law shows that the Indians are entitled to the minerals, including oil and gas, under their reserve lands. In Blueberry River Indian Band v. Canada, ${ }^{148}$ the Supreme Court of Canada held the Crown in right of Canada liable for breach of its fiduciary duty regarding a surrender of mineral rights under reserve lands in British Columbia in the 1940s. As there would have been no liability if the Indians who brought the action had not been entitled to the mineral rights, that decision unequivocally supports the position that the Indian interest in reserve lands includes subsurface resources. ${ }^{149}$ So on the basis of Dickson J.'s holding in Guerin that the Aboriginal interest in reserve and Aboriginal title lands is the same, Aboriginal title must include subsurface as well as surface rights, regardless of the use the Aboriginal peoples made of their lands prior to European colonization. As we have seen, this conclusion accords with common law principles as well as with norms of non-discrimination.

144 For more detailed discussion, see "The Meaning of Aboriginal Title," supra note 82 at 148-51. The United States Supreme Court has taken the same approach: see United States v. Paine Lumber Company, 206 U.S. 467 at $472-74$ (1907); Shoshone Tribe, supra note 139 at 115-18; Klamath and Moadoc Tribes, supra note 139 at 122-23; White Mountain Apache Tribe v. Bracker, 448 U.S. 136 at 145-46 n. 12 (1980). In Shoshone Tribe at 116, Butler J. for the Court said, in reference to land reserved by treaty, that "[f]or all practical purposes, the tribe owned the land.... The right of perpetual and exclusive occupancy of the land is not less valuable than full title in fee." Accordingly, the Shoshone Tribe's interest in the land included minerals and timber, as "[m]inerals and standing timber are constituent elements of the land itself."

14s R.S.C. 1927, c. 98. s. 2(j) [emphasis added].

146 W.F. Craies, Craies on Statute Law, 7th ed. by S.G.G. Edgar (London: Sweet and Maxwell, 1971) at 213.

117 For the same reason, and because statutes are to be construed if at all possible to preserve the rights of the Aboriginal peoples, removal of the reference to trees, wood, etc. by an amendment to this definition, S.C. 1951 , c. 29 , s. 2(1)(o), would not have diminished the Indian interest in reserve lands: see "The Meaning of Aboriginal Title," supra note 82 at 149.

149 Note that the Beaver Indians, for whom the reserve had originally been set aside pursuant to a treaty signed with them in 1916, had lived by hunting and trapping: ibid. at 37, McLachlin J. Although they made no use of the oil and gas which were only discovered under the reserve after the surrender, they nonetheless succeeded in their claim against the Crown for breach of its fiduciary duty with respect to those resources. 


\section{Conclusion}

In the Van der Peet, Adams and Côté decisions, the Supreme Court of Canada clarified that Aboriginal title is just one category of Aboriginal rights, and that freestanding Aboriginal rights such as hunting and fishing rights can exist independently of Aboriginal title. In Van der Peet, the Court created a test for identifying freestanding Aboriginal rights - the "integral to the distinctive culture" test - which it then proceeded to apply in Adams, Côté and other cases. However, as the Court has not rendered a judgment since Van der Peet involving a claim to Aboriginal title, it remains uncertain how the test might apply in that context.

Given Lamer C.J.C.'s comments on Aboriginal title in Adams in particular, it is possible that the Court will apply the test to determine the existence of Aboriginal title by requiring proof of a connection with the land that is integral to the distinctive culture of the Aboriginal claimants. If that happens, the Court may be obliged to modify aspects of the test, especially the pre-contact time frame for its application, that are not appropriate for an Aboriginal title claim. It also remains to be seen whether the Court will apply the test not only to the existence, but also to the content, of Aboriginal title.

There are compelling arguments for applying general principles relating to occupation of land rather than the "integral to the distinctive culture" test to determine the content of Aboriginal title. Those principles can be applied in a way that takes account of both Aboriginal and common law perspectives, and avoids the discriminatory consequences that would likely result from treating Aboriginal and nonAboriginal occupation of land differently by limiting Aboriginal title to uses of the land that were integral to Aboriginal cultures in the distant past. Otherwise, we could be faced with a situation where the Aboriginal peoples have a lesser interest in the lands they have occupied and used for hundreds or even thousands of years than a wrongdoer acquires by adversely possessing someone else's land for as little as ten years. Such a result would be hard to defend both domestically and internationally, and would not generate respect for Canadian law.

Judicial precedents from Australia and the United States support the conclusion that Aboriginal title is not limited to uses integral to the distinctive cultures of the Aboriginal peoples at a particular historical moment. In both those countries, the content of Aboriginal title has been determined by general principles relating to occupation of land. Moreover, by equating Aboriginal title with the Indian interest in reserve lands in Guerin, the Supreme Court of Canada has already indicated that the content of that title is not limited to historic uses. The Court has an opportunity to apply that decision in its pending judgment in the appeal of the British Columbia Court of Appeal's decision in Delgamuukw v. British Columbia, ${ }^{150}$ which was heard on June 16 and 17, 1997. The outcome of that case, which involves a claim by the Gitksan and note 82. 
Wet'suwet'en Nations to a right of self-government as well as to Aboriginal title, will have a major impact on the law of Aboriginal rights in Canada. The Supreme Court has the responsibility to clarify and develop that body of law in accordance with legal principles, existing precedents, and norms of non-discrimination. The confidence of the Aboriginal peoples in the Canadian legal system may well depend on the Court's decision in that case. 